\title{
August Boeckh, klasični filolog in hermenevtik
}

\section{Brane Senegačnik}

Univerza v Ljubljani, Filozofska fakulteta, Oddelek za klasično filologijo, Aškerčeva 2, 1000

Ljubljana

https://orcid.org/0000-0002-5182-5657

brane.senegacnik@gmail.com

August Boeckh je eden najpomembnejših klasičnih filologov 19. stoletja. Njegovo obsežno in izredno raznoliko delo je odlično izhodišče za premislek o konceptu, področjih, metodah in epistemoloških mejah klasične filologije (klasičnih študijev), danes pa tudi za interkulturni dialog. Boeckh je bil tudi vpliven metodik in eden zgodnjih teoretikov moderne hermenevtike. Opirajoč se na nauke svojega učitelja Friedricha Schleiermacherja, je zgradil razvejan sistem filološke metodologije in opredelil ciljfilologije kot "spoznanje nekoč že spoznanega". Posebej značilen za njegovo teorijo je poudarek na vlogi človeške individualnosti tako pri nastajanju kot pri razlagi besedil: individualnosti ni mogoče spoznati in opredeliti pojmovno, temveč zgolj v intuiciji (durch lebendige Anschauung). Ta ideja je zgodovinsko pomembna: individualnost je igrala zelo veliko vlogo $v$ fenomenoloških in psiholoških interpretacijah literarnega dela v 20. stoletju in sprva tudiv recepcijski teoriji; $v$ sodobnih antropoloških, kognitivnih in družboslovnih modelih raziskovanja pa izgublja svoj pomen in smisel, kar ni brez posledic za prevladujoče razumevanje literature v celoti.

Ključne besede: Boeckh, August / klasična filologija / hermenevtika / interpretacija / recepcijska teorija / Schleiermacher, Friedrich / Ingarden, Roman / Iser, Wolfgang / Bourdieu, Pierre / Ricoeur, Paul

\section{Uvod}

Osrednja tema te razprave je splošna, literarnoteoretska, njeno izhodišče pa povsem konkretno, literarnozgodovinsko: prispevek enega najpomembnejših nemških klasičnih filologov Augusta Boeckha ${ }^{1} \mathrm{k}$ teoriji interpretacije. Ta dvojnost ni naključna; v Boeckhovem delu se namreč historično

${ }^{1}$ Izvorno se je priimek zapisoval Böckh, a se je v znanstveni literaturi široko uveljavila oblika Boeckh (Hackel in Seifert 10; op. 3). Svoja številna latinska besedila je podpisoval kot Augustus Boeckhus. 
raziskovanje in teorija prepletata: literarnozgodovinske, zgodovinske in starinoslovne študije se dopolnjujejo $\mathrm{z}$ epistemologijo, z oblikovanjem koncepta in smotra (klasične) filologije, ki je najbolj zgoščeno povzet $\mathrm{v}$ njegovi znani formulaciji: »spoznanje tega, kar je proizvedel človeški duh, se pravi (nekoč že) spoznanega (Das Erkennen des vom menschlichen Geist Producirten, d.h. des Erkannten)." (Boeckh, Encyklopädie 10) Slednjemu se tu ne moremo zares posvetiti, saj je bistveno preširoko za okvir te študije; po eni strani zaradi kompleksnega kulturnega in duhovnega zaledja, iz katerega je Boeckh črpal poglavitne zamisli in vzpodbude; po drugi pa zato, ker je imelo to teoretično delo tudi čisto praktične implikacije. Bilo je namreč povezano z oblikovanjem akademskega modela študija klasične filologije na berlinski univerzi (Boeckha pogosto imenujejo »oče filološkega seminarja i) in z ustanavljanjem velikih raziskovalnih projektov, ki so še danes temeljnega pomena za to vedo. To pa so teme zgodovinarjev znanosti, idej in institucij. Iz zelo podobnih razlogov si bomo dovolili tudi terminološko poenostavitev. Čeprav namreč Boeckh velja za hermenevtika in metodologa, bomo tu skušali prikazati njegov prispevek $\mathrm{k}$ splošni teoriji interpretacije. Pojem "hermenevtika ima namreč svojo razgibano zgodovino od Schleiermacherja preko Diltheya do Gadamerja in Ricouerja in tako nikakor ni enoznačen. Boeckh sam je ta izraz res uporabljal za označevanje historične metode, ki preučuje dokumente in materialne ostanke (torej je uporabna v okviru filologije, arheologije in zgodovine) in mu morda res ne bi pripisal pomena humanistične metaznanosti, kar se zgodi šele z Diltheyem (Seebohm 183). Nedvomno pa je tako razumel filologijo (prim. Güthenke 115), ki jo je opredelil kot "raziskovanje zapisane in izgovorjene besede«, ki se poraja iz "najizvornejšega filološkega vzgiba (der ursprünglichste philologische Trieb)«, zato je zanj filologija očitno univerzalna in nujna, saj brez komunikacije ne bi bilo mogoče primerno raziskovati niti znanosti niti življenja v celoti: in zato filologija ni nič manj kot eden primarnih pogojev življenja, inherentna prvina človeške narave in temeljni člen v verigi kulture (Boeckh, Encyklopädie 10-12). Iz teh besed je očitno, da osnovna Boeckhova ideja o interpretaciji kot vsakokratnem individualnem prepoznavanju nekoč že prepoznanega (duhovno "produciranega«) presega področje, ki ga je sam označeval z izrazom hermenevtika, in je relevantna ne le za vse zgodovinske oblike hermenevtike, temveč za vsako teorijo interpretacije in pravzaprav tudi za vsako komunikacijsko teorijo. ${ }^{2} \mathrm{~V}$ tem smislu gre torej

\footnotetext{
${ }^{2}$ Sicer terminološko težavo predstavlja tudi Boeckhova uporaba izraza filologija: $\mathrm{v}$ prvi vrsti namreč govori o klasični filologiji, ki je, gledano v čisto lingvistični perspektivi, seveda bistveno ožji pojem, po drugi strani pa presega okvire ozko razumljene lingvistike, saj vključuje tudi literarno zgodovino, zgodovino, arheologijo itd.
} 
res za metodo z izredno širokim območjem uporabnosti. Po drugi strani pa ta metoda implicira določeno ontološko razlago, po kateri je človekova individualna dejavnost integralen del vsake komunikacije - takšne ontologije pa, kot je skoraj odveč pripominjati, ne sprejemajo vse komunikacijske teorije. Kakorkoli: v žarišču našega zanimanja bo tisto, kar se zdi (vsaj kot izziv) trajnega pomena za splošno teorijo interpretacije in presega ne le področje klasične filologije, temveč tudi literarne vede: to pa je misel o neponovljivosti vsakega bralnega oziroma interpretativnega akta. Ta misel sicer ne izvira od Boeckha, vendar je bil med njenimi pomembnimi zgodnjimi zagovorniki in je nekatere njene postavke formuliral v klasični obliki.

Ali je tako razumevanje hermenevtike bistveno povezano z literarnozgodovinskim področjem njegovega delovanja, s klasično filologijo? Nedvomno je povezano: Boeckhov opus, srečni primer komplementarnosti zgodovinskega raziskovanja in teorije, tako daje spodbudo za epistemološko refleksijo in za dialog med humanističnimi vedami. Vendar pa se njegov pomen nikakor ne izčrpa $\mathrm{v}$ teh historičnih navezavah. Osrednja tema te razprave so zato domet relevantnosti njegove (na Schleiermacherjevi utemeljene) hermenevtike in njene implikacije za literarno vedo skozi 20. stoletje do danes. Na robu in že onstran refleksijskega kroga te razprave pa se odpira vprašanje, kaj upoštevanje njenih premis pomeni za literarno ustvarjanje in celo za razumevanje kulture $v$ najširšem pomenu.

\section{August Boeckh - klasični filolog}

August Boeckh (1785-1867) nesporno sodi med največja imena klasične filologije 19. stoletja (Hackel in Seifert 10). Njegov opus je fascinanten tako po širini raziskovanja in pomenu rezultatov kot po konceptualni temeljitosti. S svojo enciklopedičnostjo presega osnovne okvire klasične filologije in ne sega le na območje primerjalne književnosti, temveč tudi številnih drugih ved. Je eden glavnih tvorcev znamenitega koncepta Altertumswissenschaft, ki je bistveno določal nemško klasično filologijo v predpreteklem stoletju, in obenem eden njegovih najodličnejših predstavnikov, tako rekoč njegovo utelešenje. ${ }^{3}$

Očitno je, da Boeckh s filologijo označuje tako rekoč sleherno obliko interpretacije in komunikacije. Zaradi tega mislim, da terminološka ohlapnost ni ovira, da bi njegove poglede razlagali kot prispevek k splošni teoriji interpretacije (oziroma hermenevtike $\mathrm{v}$ takšnem pomenu).

${ }^{3} \mathrm{Za}$ vsestransko temeljit, kritičen in obenem pregleden prikaz Boeckhovega dela in kariere glej Hackel in Seifert. 
Nesporen je Boeckhov prispevek k pozitivistično zasnovani klasični filologiji: četudi je vsebina njegovih raziskav morda nadgrajena, presežena, korigirana, je vendarle trajno (pa četudi »nevidno«) vgrajena $\mathrm{v}$ temeljno leksikonsko vedenje o antiki. Važna je vrsta starinoslovnih študij, od ekonomskih (Die Staatshaushaltung der Athener, 1817 in 1851, s suplementom Urkunden über das Seewesen des attischen Staats) in meroslovnih (Metrologische Untersuchungen über Gewichte, Münzfüsse, und Masse des Alterthums, 1838) do kronoloških (Zur Geschichte der Mondcyclen der Hellenen, 1855; Über die vierjährigen Sonnenkreise der Alten, 1863), filozofsko-astronomskih ${ }^{4}$ in seveda zlasti epigrafskih (Epigraphisch-chronologische Studien, 1856). Prav posebno trajnega pomena je veliki epigrafski projekt berlinske univerze Corpus Inscriptionum Graecarum $(C I G)$, namenjen objavi vseh znanih grških antičnih napisov (1828-1877), katerega prvi urednik je bil Boeckh. Druga dva dela od štirih sta izšla po Boeckhovi smrti, projekt pa se je nadaljeval pod vodstvom Ulricha von Wilamowitz-Moellendorffa ( $\mathrm{v}$ letih 1902-1931) in postavil temelj ene najpomembnješih zbirk virov za klasične študije. Od leta 1994 izhaja zbirka pod okriljem BerlinBrandenburgischen Akademie der Wissenschaften.

Posebno mesto v Boeckhovem opusu imata dve izdaji. Še zlasti velja za prelomno izdaja Pindarjevih epinikijev v treh zvezkih (1811-1821), ki vsebuje besedilo, kritični komentar, sholije in latinski prevod. Najvplivnejši del te izdaje je metrična študija (De Metris Pindari), ki je del prvega zvezka. V njej je Boeckh utemeljil novo členitev epinikijev po verzih, in sicer na kolometričnih načelih, za katera je verjel, da so pristna in da so se zabrisala v aleksandrinski redakciji. ${ }^{5}$ Izdaja Sofoklove Antigone (1843) je povezana z njegovim dolgoletnim raziskovanjem te tragedije in grškega tragiškega pesništva. Razumevanje, ki ga Boeckh kaže za Kreontovo stališče v razpravi »Über die Antigone des Sophokles« iz leta 1824, ni zelo daleč od Heglove interpretacije. ${ }^{6}$ Njegova avtoriteta

\footnotetext{
${ }^{4}$ De Platonica corporis mundani fabrica, 1809; De Platonico systemate caelestium globorum et de vera indole astronomiae philolaice, 1810; Manetho und die Hundsternperiode, 1845. Te razprave se ukvarjajo s Platonovim naukom o zgradbi sveta in so zelo specifičen del njegove filozofije.

${ }^{5}$ Čeprav se je ta členitev izredno široko uveljavila, pa problem očitno ni dokončno rešen. Boeckhova stihometrična načela kritizirajo včasih celo $\mathrm{z}$ argumenti kognitivne psihologije (Willett), odpira pa se tudi vprašanje, ali so filologi, ki so sprejeli in utrdili Boechkovo razlago metričnih pravil, le-to sploh pravilno povzeli (Tessier, "Sticometria«; "De pauore«).

${ }^{6}$ Boeckh je to predavanje ponovno predstavil v klasičnem seminarju leta 1828 . Hegel je bil v tem času Boeckhov profesorski kolega na berlinski univerzi; res pa je svojo interpretacijo Antigone najnatančneje razdelal že prej, v Fenomenologiji duha (1807).
} 
na tem področju je botrovala tudi sodelovanju pri projektu prve uprizoritve Sofoklove Antigone z avtentističnimi težnjami v Potsdamu leta 1841, pripravljene po naročilu pruskega kralja Friedricha Wilhelma IV (najmočnejšo sled v kulturni zgodovini je pustila ta predstava z glasbo, ki jo je posebej zanjo napisal Felix Mendelssohn-Bartholdy). ${ }^{7}$

Koncept klasične filologije je Boeckh razvijal predvsem v svojih predavanjih in v govorih, ki jih je imel ob raznih priložnostih (mnoga od teh besedil so v latinščini). ${ }^{8} \mathrm{~V}$ njem je razdelal Wolfove ideje o tem, da je klasična filologija celovito zgodovinsko in filozofsko vedenje o antiki (cognitio universae antiquitatis), ki obsega pet področij: poznavanje državnih ustanov, časov in krajev; zasebnega življenja; religioznega in umetniškega življenja starih ljudstev; zgodovine etičnih in naravoslovnih prepričanj in književnosti; in celovito razlago jezika. Nosilna ideja njegovega znanstvenega projekta je historična rekonstrukcija celotnega življenja v antiki - to pa je seveda nadindividualna, tudi nadgeneracijska naloga, ki naj združuje delo mnogih učenjakov skozi čas.

$\mathrm{Ni}$ torej presenetljivo, če Boeckhova enciklopedična misel postaja aktualna $\mathrm{v}$ časih velikih transformacij, ki zahtevajo refleksijo epistemoloških temeljev in medkulturni dialog. Na Humboldtovi univerzi je bil leta 2005 ustanovljen center z njegovim imenom (August-BoeckhAntikezentrum), katerega namen je spodbujanje in koordinacija interdisciplinarnih dejavnosti in raziskovalnih in študijskih projektov na področju klasičnih študijev. Obsežna in raznolika dediščina tega »velikega neznanega filologa iz 19.stoletja« (King) je v zadnjem času tudi predmet sistematičnih raziskav (Hackel in Seifert; Poiss, "Die unendliche«; Horstmann; Doborosky), obenem pa tudi izhodišče in izziv za razmislek o konceptu, medsebojnih razmerjih in ciljih posamičnih humanističnih ved.

\section{Dinamična tla realnosti in nestalne epistemološke meje}

Meje med posameznimi (humanističnimi) vedami so nejasne in premične in četudi so medsebojno odvisne, jih včasih zaznamuje tudi težko presegljiv antagonizem. Metateoretični epistemološki okvir in harmonizacija posameznih epistemoloških polj oziroma radikalno divergentnih

\footnotetext{
${ }^{7}$ Prim. Senegačnik, »Hribovškova« 121; Steinberg 110-111.

${ }^{8}$ Prvine tega koncepta so razkropljene po mnogih besedilih, ki jih najdemo v različnih zbirkah: najpomembnejša je Encyclopädie und Methodologie der philologischen Wissenschaften, v kateri je Ernst Bratuschek leta 1877 izdal njegova predavanja iz let 1809-1865. Za sodobno sintetično obravnavo glej Danneberg, "Kunst«; Horstmann.
} 
metodološko konstituiranih svetov posameznih ved sta torej vprašljiva koncepta, ker posamezne perspektive neredko zakrivajo ali izključujejo druga drugo in s takšnimi medsebojnimi razmerji onemogočajo svoj soobstoj. Po drugi strani pa je jasno vidno tudi, da ostro razmejevanje ved vodi v redukcijo predmeta raziskav. V zelo zoženi specifični epistemološki perspektivi je predmet sicer mogoče $\mathrm{z}$ določenega vidika močno osvetliti, ga tako rekoč »rentgenizirati«, a je tedaj postavljen v neki širši in obenem ožji svet, ki ga konstituira ta perspektiva, in vprašanje je, če taka obravnava morda ne zastira drugih njegovih vidikov ali pa vzpostavlja problematično hierarhijo le-teh. Dramsko delo, npr. Sofoklovega Kralja Ojdipa ali Evripidove Bakhe, je mogoče analizirati, denimo, s čisto jezikoslovnega, psihološkega ali sociološkega vidika in ga umestiti v okvire katerega od teh epistemoloških svetov. Podobe dela, ki se odkrivajo s teh perspektiv, pa se pogosto ne ujemajo, še več, neredko so neuskladljive, celo nepovezljive, ker se posamezni teoretični okviri in metodologije včasih ignorirajo ali celo izključujejo.

Tisto, kar je s čisto epistemološkega vidika ne le mogoče, temveč celo vitalnega pomena, pa je refleksija posameznih teoretičnih okvirov, ki začrtuje domet posameznega pristopa, njegovo razmerje do predmeta in s tem tudi meje njegove relevantnosti. Na ta način se vsaj nakazuje tudi širše ozadje, na katerem so teoretične podobe raziskovanega predmeta (npr. literarnega dela) če že ne komenzurabilne, pa vsaj primerljive. Načelni epistemološki anarhizem, če uporabim Feyerabendov pojem, s tem sicer ni odpravljen, je pa zajezen $\mathrm{z}$ nekim relativnim in spremenljivim, a vendarle sorazmerno zanesljivim merilom, ki je pragmatično zasidrano $v$ predmetu samem. $V$ našem primeru to pomeni: $\mathrm{v}$ konkretnem besedilu, ki je del jezikovne in kulturne resničnosti časa svojega nastanka in ki zato vsakokratnega interpreta izziva tudi k mnogostranski samorefleksiji lastnega hermenevtičnega položaja.

Poseben vidik pri opredeljevanju razmerij med posameznimi vedami predstavlja njihova lastna zgodovina. Koncept klasične filologije je seveda novoveški, celo moderen, ni pa moderen njen predmet oziroma temeljno področje njenega raziskovanja: antična (pa tudi srednjeveška in zgodnjenovoveška) besedila. ${ }^{9}$ Konceptualno razpršenih sodobnih klasičnih študijev ni mogoče zajeti v okvir Altertumswissenschaft, ki je dominirala v 19. stoletju; in slednja seveda ni personificirana Filologija iz slovite enciklopedične alegorije Poroka Filologije z Merkurjem (De nuptiis Philologiae et Mercurii) Marcijana Kapele s konca antike. A to ne pomeni, da je ta poznoatnični prosimetrum (avtorjev floruit veči-

${ }^{9} \mathrm{~V}$ določeni meri to seveda velja tudi za primerjalno književnost in literarno vedo nasploh. 
noma postavljajo v leta 410-420), ki je tako močno vplival na srednjeveške izobrazbene in kulturne ideale, brez vrednosti za razumevanje širšega konceptualnega zaledja klasične filologije. Nasprotno, je legitimni del izredno dolgega, širokega in razvejanega toka tradicije, ki vključuje tako intertekstualno in intratekstualno refleksijo in kritiko kot različne oblike teoretičnega raziskovanja in klasificiranja literature. Ta tradicija razkriva številne oblike kontinuitete in diskontinuitete, medsebojne povezanosti in medsebojne odvisnosti posameznih konceptov, pa tudi njihovih konfrontacij in artikulacij preko distanciranja in odklonov, ki so privedli do specializacije in konstituiranja novih področij vedenja, novih metodologij, novih ved in njihovih epistemoloških svetov. Kje lahko vidimo začetke refleksije literature? In kakšen pomen imajo lahko le-ti za literarno vedo v pravem pomenu? So filozofske interpretacije in etične kritike Homerja, od tistih najzgodnejših pri Ksenofanu in Teagesu iz Regiona do Proklovih s samega konca antike, literarna kritika ali interpretacija? So tedaj že tudi del literarne vede? Ali pa se vse zares začne šele s helenistično tekstno kritiko, kot je veljalo po tradicionalnem gledanju? ${ }^{10}$ Tudi tekstna kritika, najosnovnejša panoga klasične filologije, je neločljivo vpeta $\mathrm{v}$ širši obod literarne vede: za polno semantično rekonstrukcijo rokopisov z antičnimi besedili je namreč poleg povsem specifičnih znanj posameznih panog (papiroloških, paleografskih, novih tehničnih metod za raziskavo materialov) nepogrešljivo tudi poznavanje literarne zgodovine, raznih literarnoteoretičnih metod in izsledkov družboslovnih ved, tudi tistih novejšega izvora. Vse to je povsem skladno s premestitvijo fokusa interpretativnega interesa $\mathrm{v}$ sodobnih klasičnih študijah: ta se je s teksta premaknil na kontekst, kot je to strnjeno formuliral Charles Segal (Segal 4). Posledica te premestitve (in anglosaškega kulturnega vpliva) je, da se namesto o klasični filologiji vse bolj govori o klasičnih študijih.

Če strnemo: klasična filologija je lahko kljub nestalnimi in odprtim mejam razumljena kot povsem samostojna veda, lahko pa tudi kot podporna veda jezikoslovja, primerjalne književnosti, splošne literarne vede, zgodovine itd. Na podlagi zgodovinske izkušnje je torej mogoče govoriti in utramque partem, poudarjati to povezavo ali jo relativirati. Odgovori na vprašanja o prelomu in kontinuiteti, epistemoloških mejah in samostojnosti, so odvisni od perspektive. A kakršnokoli perspektivo že zavzamemo, se zdi, da klasična filologija (ali klasični študiji) tudi brez ostro zarisanega teoretičnega okvira ohranja smisel kot posebna veda z lastnim vsebinskim fokusom, ki s tradicionalnimi koncepti in

${ }^{10} \mathrm{Na}$ lapidaren način je tak pogled na zgodovino klasične filologije utemeljil Rudolf Pfeiffer (Pfeiffer 114-132). 
metodologijami pridobljeno vednost nenehoma rekontekstualizira, preverja, revidira in dopolnjuje v svetu razvijajočih se novih znanosti.

\section{August Boeckh - hermenevtik}

August Boeckh je tudi eden od osrednjih likov eruditske in obenem navdihujoče knjige Constanze Güthenke o romantičnem izvoru znamenitega koncepta Altertumswissenschaft. Delo z zgovornim naslovom Feeling and Classical Philology, bogato z obširnimi analizami kulturnega in idejnega zaledja tega pomembnega momenta $\mathrm{v}$ zgodovini humanistike, lepo izrisuje tudi osnovne poteze Boeckhove hermenevtike. Najgloblja težnja, najpristnejši vzgon žene filologa k spoznanju celote njegovega predmeta. Ta predmet je zgodovinski: antična doba. Zgodovinskost predmeta raziskovanja je obenem prednost in ovira: zaradi časovne oddaljenosti je antika že dokončno izoblikovana celota (kar ne velja za poznejša obdobja in seveda predvsem ne za sodobnost); zob časa, ki nam je pustil od nje le fragmente, pa je otežil njeno razumevanje. In vendar se tudi to obrača v svojsko prednost: za dojetje oddaljenega in fragmentiranega predmeta je potreben in s tem osmišljen večji rekonstrukcijski napor, več pristnega filološkega dela (Güthenke 116). Boeckh je raziskovanje antike razširil, poenostavljeno rečeno, prek meja literature na celotno kulturo: $s$ tem je postalo spoznanje celote posameznemu filologu še teže dosegljivo in neizbežno je bilo povezati delo številnih (generacij) raziskovalcev v velikih projektih (kakršen je bil npr. $C I G$ ). Pred filologom je tedaj, tako kot pred vsakim znanstvenikom, eine unendliche Aufgabe der Approximation, neskončna naloga približevanja svojemu predmetu (prim. Boeckh, Encyklopädie 16). A težnja po spoznanju celote vendarle ostaja v osrčju prave filologije in spoznanje je inidividualno dejanje - kako torej najti pot iz te zagate? Neizbežno fragmentarnost predmeta in njegovih spoznanj je mogoče preseči le z veliko ljubeznijo do filologije (die grosse Liebe): samo ta zagotavlja, da je ideja celote resnična in da je mogoča celovita rekonstrukcija antičnih duhovnih konstrukcij. Gibalo neskončnega približevanja, ki daje znanstvenemu spoznavanju enotnost, je torej sámo v bistvu neznanstveno in celo ne-racionalno. Iz nje izrašča tudi odločilni element filološkega spoznavanja: občutje (Gefühl). To je posebej povezano s filologijo kot jezikovno vedo. Ker je vsa kultura, tako duhovna kot materialna, proizvod človeškega duha, najustreznejši izraz razumevanja duha pa jezik, je filologija - raziskovanje izgovorjene ali zapisane besede - nekakšna metaznanost, ki zaobsega območja vseh posameznih disciplin (Boeckh, 
Encyklopädie 10-11). Hermenevtika se tako deli v objektivni (gramatična in historična ${ }^{11}$ interpretacija) in subjektivni (žanrska ${ }^{12}$ in individualna interpretacija) del. Ključni moment je v zadnji: vsako besedilo je namreč individualno oblikovano, vanj je vtkana sled avtorjeve individualnosti (fremde Individualität), ki je ni mogoče zajeti v splošne oblike vedenja. Individualnost ima sicer različne pojavne oblike, ki jih določajo objektivna in žanrska določila in njena lastna zgodovina (to Boeckh označuje kot njeno Vielheit, mnogoterost), vendar je v vseh teh izrazih ena in ista - je namreč splošni značaj vseh posameznih pojavnih oblik in kot taka nedotakljiva. ${ }^{13} \mathrm{Ta}$ individualnost se izraža $\mathrm{v}$ avtorjevi dejavnosti na ravni kompozicije besed: $\mathrm{v}$ njej je namreč bistvo individualnega stila. Zato je z interpretacijo, ki je omejena zgolj na uporabo tehničnih veščin in znanja, kompleksni izraz tuje individualnosti mogoče razvozlati le do neke mere, medtem ko ga lahko povsem dojamemo samo v nenadnem prepoznanju (mit einem Schlage wiedererkannt wird), ki se zgodi v živem uzrtju (durch lebendige Anschaunng). To uzrtje, ki se pripeti le redko (in zdi se, da ga ni moč izsiliti), je dano v občutju: ne zgodi se torej (v celoti) preko splošnih jezikovnih pravil, temveč neposredno s stikom dveh individualitet, kar Boeckh podčrta s starim grškim reklom, da lahko samo podobni spozna podobnega. To občutje, ki vznika iz podobnosti interpretovega duha $\mathrm{z}$ duhom, izraženim v razlaganem besedilu, deluje sponatno, iz samega sebe, in je "notranje produktivno«: zaradi njega "na mesto razumevanja stopi fantazija kot hermenevtična dejavnost" (Boeckh, Encyklopädie 86-87). Temu, kar avtor s svojo individualno uporabo jezika pristavi $\mathrm{k}$ splošnosti pravil, mora odgovoriti individualni pristavek interpreta; gre za neposplošljivo in nepogrešljivo individualno dejavnost, ki edina lahko privede do dojetja individualnega izraza na "intersubjektivni« ravni. ${ }^{14}$ Individualnega sloga torej ni mogoče popolnoma določiti pojmovno, temveč ga lahko samo zrenjsko

${ }^{11}$ Ta se ukvarja s pragmatičnimi določili konkretne uporabe besed in jezikovnih pravil v razlaganem besedilu oziroma s historičnim kontekstom.

${ }^{12}$ Namen in smer uporabe besed in jezikovnih pravil, kot jih določajo žanrske konvencije.

${ }^{13}$ "Sie ist der allgemeine Charakter aller einzelnen Lebenserscheinungen, unantastbar als das Allerheiligste der Menschennatur.» (Boeckh, Encyklopädie 125-126)

${ }^{14}$ Boeckhova ideja hermenevtike kot spoznavanja že spoznanega se zdi v neskladju s Schleiermacherjevo idejo kreativne lektire (produktivnega razumevanja), v kateri bralec dodaja nove pomene (glej Frank, Das Sagbare 137-140). Edino možnost na tej točki uskladitve vidim v tem, da se celovito živo uzrtje pomena, intuicija (kot izraz prevaja Güthenke 119), zgodi s preskokom na drugo raven od tiste, kjer poteka ustvarjalno razumevanje in nastaja prirast pomena. 
reproduciramo s hermenevtiko kot načinom zrenja. ${ }^{15}$ Pravi interpret je zato prej kot znanstvenik hermenevtični umetnik (hermeneutischer Künstler): med njegove nujne odlike sodi tudi prirojeni talent (Boeckh, Encyklopädie 86). ${ }^{16}$

Nedvomno je v vsem tem lahko prepoznati močan Platonov vpliv: navsezadnje je naloga filologov razumevanje Platona, čigar delo zajema vse veje človeškega vedenja (Boeckh, Encyklopädie 9). Nič manj kot vsebina njegovih besedil so pomembne tudi Platonove predstave in metode spoznanja, zlasti tiste iz Simpozija in Fajdra (Güthenke 117-118). Po Boeckhovih predstavah se v pravem filologu prepletata Platonov zaljubljenec v spoznanje in Ciceronov idealni govornik (Güthenke 120) in zagotovo lahko vidimo podlago za tako predstavo $\mathrm{v}$ kvazi-personalnem odnosu s poosebljenimi deli in antiko v celoti, ki je bil značilen za nemške učenjake $v$ romantični dobi (2). Vendar se pomen Boeckhove schleiermacherjanske misli ne izčrpa niti v nostalgičnem idealiziranju Platonovega spoznavnega erosa niti $v$ naivni emocionalno motivirani personifikaciji teksta. Pomen individualnosti v Schleiermacherjevi hermenevtiki skušajo novejši kritiki docela zgodovinsko razložiti oziroma nevtralizirati zlasti po dveh poteh. Eni ga zvajajo na Schleimacherjev "organicizem", na analogijo njegovega nauka z vplivnimi koncepti organskosti v sočasni biologiji (Forster 112-113; Lane 8). Drugi pa menijo, da je motiv za konstruiranje dejavnega avtorja izza besedil (po biblični eksegezi oblikovan) poskus preložiti odgovornost za neskladnosti in nedoslednosti v besedilih nanj, namesto da bi jih iskali tam, kjer "realno" so: v dvoumnih in nekonsistentnih strukturah samih besedil (Danneberg, "Ganzheitsvorstellungen«). Vendar ne avtor ne bralec nista konstrukciji, temveč factum brutum; konstrukcije so - in to $\mathrm{v}$ emfatičnem pomenu - besedilne strukture. To dejstvo v večji ali manjši meri zadeva sleherni interpretacijski in komunikacijski akt, v katerem so ljudje neposredno udeleženi (torej kjer ne gre za strojno kodiranje in dekodiranje). $\mathrm{V}$ tem pogledu za Boeckha, ki se tega jasno zaveda, res lahko velja oznaka filozofa Manfreda Franka: eden velikih pozabljenih metodikov hermenevtične stroke (Frank, Selbstbewußtsein 52).

15 "So ist auch der individuelle Stil nicht vollständig durch Begriffe zu charakterisiren, sondern durch die Hermeneutik als Anschauungsweise selbst anschaulich zu reproduciren.« (Boeckh, Encyklopädie 127)

${ }^{16} \mathrm{Tu}$ Boeckh priredi Ruhnkenovo misel o kritiku: Criticus non fit, sed nascitur, za interpreta: Interpres non fit, sed nascitur. Pravi interpret torej ne moreš postati (s pridobivanjem veščine), temveč se moraš s tem darom roditi (Boeckh, Encyklopädie 87). Obe izjavi sta prirejeni po izreku o pesniku in govorniku Poeta nascitur, orator fit, za katerega zgodovino glej Ringler. 


\section{Dodatna osvetlitev in implikacije individualne interpretacije}

$\mathrm{Na}$ neki način drži izvajanje Erica Donalda Hirscha, ki je, oprt na Bettijevo splošno teorijo interpretacije, Boeckha skupaj $s$ Schleiermacherjem uvrščal $\mathrm{v}$ tradicionalno hermenevtiko, katere težnja naj bi bila dognati objektivno veljavni pomen besedila, zlasti pa tako imenovani authorial meaning: od avtorja zamišljeni in od interpreta relativno neodvisni pomen (Hirsch, Validity; The Aims). Če je namreč hermenevtično odkrivanje pomena prepoznavanje nekoč že spoznanega, potem, strogo ontološko vzeto, ta pomen mora že obstajati neodvisno od interpretove dejavnosti. Toda iz kratke skice Boeckhove teorije v zgornjih vrsticah je jasno, da hermenevtične interpretacije ni imel za docela objektiven postopek, v katerem bi se pomen besedila, fiksiran s splošnimi jezikovnimi pravili, lahko v polnosti reproduciral le s korektno uporabo slednjih. Zato prava interpretacija ne more biti zgolj sledenje jezikovnim pravilom, temveč mora interpret na podlagi upoštevanja le-teh pravi pomen besedila divinirati, kot je to imenoval Schleiermacher. Divinacijo, ključni pojem Schleiermacherjeve teorije jezika, Frank razlaga kot konjekturno hipotezo, izvorno (torej neizpeljano) razumevanje, ali preprosto kot uvid (Frank, Das Sagbare 33). ${ }^{17}$ Ta kreativni vidik, ki ga je Boeckh imenoval »individualni pristavek (individueller Beisatz)« je torej strukturni, sestavni moment slehernega interpretacijskega akta in pravzaprav vse (naravne) jezikovne komunikacije (Boeckh, Encyklopädie 83). Zaradi tega individualnega prispevka je slog individualna kategorija.

Poskusimo to še nekoliko osvetliti s Frankovim povzetkom ključnih Schleiermacherjevih misli (Schleiermacher 172-173): objektivne strukture jezika (sintaksa, semantika, pragmatika) konstituirajo nujne pogoje za uporabo jezika, vendar pa nobena izmed njih ni s tem že prepoznana kot vzrok, ki sproži individualno kombiniranje, v katerem se »energeia" besedilnega subjekta manifestira v svoji "posebnosti«, ki je nikoli ni mogoče izsiliti iz takšnih ali drugačnih pravil in zatorej tudi nikoli popolnoma shematizirati. Posebnosti nekega sloga tedaj ni mogoče »konstruirati a priori«, njegova individualnost ni gramatično zajemljiva v pojmu; in za nobenega izmed slogov ni mogoče podati kakršnega koli pojma (Frank, Das Sagbare 178). ${ }^{18}$

\footnotetext{
${ }^{17}$ Za slovenski prevod Frankove razprave glej Frank, »Besedilo«.

${ }^{18}$ Prim. tudi Humboldtovo misel, da v vsaki situaciji jezikovnega sporazumevanja - celo v posebnem primeru sporazumevanja o sebi in sporazumevanja o besedilih - zadeneta drug ob drugega dva predstavna načina, izmed katerih se prekriva zgolj
} 
Toda ta poudarek romantičnega znanstvenika na individualnosti $\mathrm{v}$ resnici ne zanika globokega smisla njegovega znanstvenega dela: individualno je namreč samo en element - nepredvidljiv, nenadzorljiv - svobode in diskontinuitete, v kompleksnem svetu interpretacije, ki sicer temelji na splošnem vedenju in znanju. Individualni slog se ne upira pravilom, temveč jih predpostavlja; slogovne inovacije so kot svetloba smisla, v katerih se znaki besedila (jezikovna pravila) drugače obarvajo oziroma razvijejo svojo kromatiko. Je mogoče te inovacije vendarle razumeti tudi kot modifikacije splošnih pravil? Nedvomno, vendar samo post festum, v naknadni refleksiji, potem ko smo smisel teh novih izrazov že prej divinirali (Frank, Das Sagbare 32). Tu je potrebno upoštevati dvoje: zgodovinsko perspektivo in raven, na kateri se kaže slogovna inovativnost. Nekoč novi izrazi lahko skozi čas s pogosto uporabo postanejo vzorec in otrdijo $\mathrm{v}$ maniro, značilno za avtorjev individualni slog (npr. homerske primere, »dantizmi«) ali pa za slog kake literarne smeri (npr. nadrealistična metaforika). Zlasti pa je pomembna pozornost na raven, na kateri opažamo inovativnost. Individualni pesniški slog se namreč najmočneje razodeva ravno v takšnem oblikovanju jezika, ki se izmika retorični shematizaciji in ravno zato je, kar je: neposplošljiv, edinstven, individualen in je primarno dostopen $\mathrm{v}$ uvidu oziroma doživljaju. Slednje še prav posebej jasno kaže na divinacijski značaj avtentične hermenevtike pesniških besedil, ki pa ima svoje meje oziroma položaj, na katerem je smiselna. Divinacija ima torej svoj smisel samo v okviru kompleksnega interpretativnega akta, tako, kot je, naj ponovimo, individualni prispevek, četudi integralen del komunikacije, vendarle samo njen majhen del. Frank to opiše kot »komaj izsledljivo potezo individualnega na splošnem, kot nežno nihanje jeklenega ohišja« (Frank, Selbstbewußtsein 74).

Seveda je vloga tega individualnega prispevka zelo različna v žanrsko različnih besedilih, bolje rečeno $\mathrm{v}$ različnih tipih besedil, $s$ čimer mislim predvsem na to, kakšni obliki razmerja z resničnostjo pripada kako besedilo. Ta pragmatična zasnovanost implicira takšno ali drugačno uporabo jezika. Koncept individualnega sloga je zato seveda relevanten predvsem za umetniška (še zlasti pa pesniška, in še prav posebej za lirična) besedila, ki oziroma kolikor niso strogo določena s funkcionalno pragmatiko (kot so npr. tehnična navodila, poročila, znanstvena besedila itd., kjer je možnost popolne reproducibilnosti seveda bistvena). Tudi umetniška besedila so sicer najpogosteje sestavljena iz

konvencionalni del, medtem ko »individualni štrli čez« (Humboldt 418). Za slovenski prevod tega pasusa glej Frank, »Besedilo«. 
vrste takšnih stavkov, pri katerih se predpostavlja popolna reproducibilnost, da sploh lahko delujejo, vendar pa kot celota niso pragmatično določena na tak način, saj so $\mathrm{z}$ resničnostjo povezana bistveno drugače. $\mathrm{V}$ temelju so zaznamovana $\mathrm{z}$ drugačnim konceptom resničnosti: njihovo »ozadje« ni zgolj pragmatično (strogo naravoslovno in sociološko) razumljena objektivna resničnost. To pa seveda ne pomeni, da s slednjo niso povezana; nasprotno, ta povezava je nujna in kompleksna, a nikakor ne absolutna $\mathrm{v}$ tem smislu, da bi tako opredeljena resničnost absorbirala vso »logiko« literarnega besedila. Razmerje umetniške resničnosti in njenega razmerja $\mathrm{z}$ resničnostjo nasploh je seveda eno velikih vprašanj ne le teorije umetnosti, temveč tudi ontologije: ali je umetnost zožitev in distorzija resničnosti ali pa morda njen "živi« del, ki kaže na njeno odprtost, nezvedljivost na pragmatično-realistično obzorje? Kar lahko tu rečemo, je, da je to vprašanje komajda mogoče relevantno obravnavati, brez upoštevanja različnih vidikov individualnosti, ki jih v okviru jezikovne komunikacije odkriva Boeckhova oz. Schleiermacherjeva hermenevtika.

Boeckh je raziskoval in ugotavljal filološko podobo antičnega besedila izjemno natančno in obenem široko. To se jasno kaže ob načelih, ki jim je sledil pri oblikovanju integralne izdaje Pindarja: "Odločitev glede najmanjšega besedilnega detajla je treba v večkratnih cikličnih primerjalnih procesih povezati s celotno pesnitvijo, avtorjevim delom, s splošno, individualno in zvrstnotipično jezikovno rabo in jo tako preizkusiti; in vsak metrični detajl se mora preveriti ob zanesljivosti preoddaje besedila in ob izmenjavi metričnih pravil.» (Poiss, "August« 36) Ta znanstvena načela implicirajo mnogo več kot golo semantično analizo in nedvomno zajemajo tudi pragmatiko $\mathrm{v}$ najširšem pomenu besede. Če to povežemo $s$ poudarjanjem kreativne vloge individualnega elementa, zlasti seveda recipienta, bralca ali poslušalca, lahko očrtamo tri območja ali momente, ki določajo vsako individualno interpretacijo: kulturni makropoložaj interpreta, njegov eksistencialni mikropoložaj in pa njegovo lastno dejavnost (pobudo). Prva dva momenta sta splošno določljiva (čeprav izredno težko v izčrpni obliki), zadnji pa ne, saj je svobodna pobuda in kot taka sistemsko nezajemljiv. Izvira namreč iz ideje individuuma kot enkratnega, dejanskega in zato neposplošljivega bitja. Ta ideja, ki jo povzema latinska krilatica individuum ineffabile, je dobila največji poudarek prav v romantiki, pri tistih mislecih torej, $\mathrm{v}$ katerih intelektualno obnebje sodi August Boeckh. 


\section{Zgodovinske razširitve}

Takšna predstava o individuumu in $\mathrm{z}$ njo povezano razumevanje literarnega sloga, interpretacije in recepcije po svoji "globoki« filozofski osnovi ni združljiva s scientistično paradigmo družboslovja, ki - tako se vsaj zdi - vse bolj oblikuje tudi raziskovalno politiko humanistike. Individuum je namreč lahko vir inovacije samo, če ni v celoti zvedljiv na noben sistem: ne na jezikovni ne na socialni, biološki, fizikalni itd. Če torej ni razumljen zgolj kot posebnost, ki pa je $v$ bistvu še vedno razložljiva s pravili. Posameznega bralca imamo lahko za dejanski vir jezikovne (slogovne) inovacije samo, če dopustimo, da je vsaj v neki meri svoboden pri kombiniranju, a tudi preoblikovanju zgodovinsko in družbeno danega jezikovnega sistema, in ne vidimo v njem zgolj uporabnika sistemsko (kodno) že vnaprej popolnoma določenih jezikovnih možnosti ( $s$ katerimi bi bilo mogoče $\mathrm{v}$ celoti razložiti tudi njegov individualni izraz oziroma slog) ali pa celo zgolj imaginarno instanco, skozi katero se dejansko reproducirajo splošni vzorci spolno, ideološko oziroma kulturno ali kako drugače določnega nezavednega. Izraženo $s$ prispodobo: individuum je realna instanca oblikovanja pomena, samo če v njem ne vidimo nekoga, ki se vozi po jezikovnih tirnicah ali pa si to celo samo domišlja, saj ga $\mathrm{v}$ resnici vozijo te tirnice same po družbeno strukturiranem voznem redu nezavednega-realnega. Drugače rečeno: problem individualnosti literarnega sloga ima svoje korenine $\mathrm{v}$ tem radikalnem antropološkem ali ontološkem vprašanju.

Kreativna vloga recipienta je bila v 20. stoletju deležna močnega poudarka in kompleksnih teoretičnih razlag, ki so iskale njene objektivne temelje $\mathrm{v}$ posebni oblikovanosti literarnih besedil. Zlasti pesniška in še posebej lirična besedila namreč ne učinkujejo le s pomeni, $\mathrm{z}$ mentalno vsebino $\mathrm{v}$ ožjem smislu, temveč tudi z zunanjo in notranjo formo, kamor sodijo mentalne podobe, čutni, zvočni učinki in ritem. Ti objektivni temelji (posebna izoblikovanost besedil) pa imajo po drugi strani najpomembnejši izvor $\mathrm{v}$ individualnem elementu, $\mathrm{v}$ posebnem "posluhu" (domišljijski kreativnosti in zvočni občutljivosti) najprej avtorja in potem recipienta. Nekateri fenomenologi (Emil Staiger, 1908-1987) in globinski psihologi (Erich Neumann, 1905-1960) so močno poudarjali, da celovita recepcija npr. pesniških umetnin recipientu ne omogoča samo razumevanje njihovega semantičnega smisla, temveč tudi drugačno samodoživetje in razmerje s celotno resničnostjo. Svoje teze so razvili vsak na svojem področju in neodvisno, skupno pa jim je to, da jih niso imeli za čisti teoretični model, temveč so jih utemeljevali bodisi v bralni izkušnji bodisi v spoznanjih, nastalih v kli- 
nični psihološki praksi (prim. Neumann). Implicitna predpostavka $v$ njihovih izvajanjih je tudi, da takšno doživljanje ni razpoložljiv, nujen in zanesljiv učinek pesniškega besedila, vsekakor pa je bistveno povezano z dejavno ali celo kokreativno vlogo individualnega recipienta. Obema tokovoma je skupna tudi predstava o možnem preseganju besedila kot zgolj semantične teksture z doživljanjem imaginativnih in zvočnih elementov, ki jih individualni bralec lahko oživi in doživi v ustreznem bralnem aktu. Ta predstava ima za podlago odprt odnos med bralcem in besedilom, ki je utemeljen v posebni ontološki zgradbi slednjega. Na to posebnost literarnih besedil kaže njihova specifična zgradba, kar je najnatančneje prikazala fenomenologija z Ingardnovimi ontološkimi študijami o plasteh literarnega dela in njihovih vlogah. ${ }^{19}$ $\mathrm{V}$ literarni umetnini je Ingarden razločeval štiri plasti: plast zvenskih tvorb, plast pomenskih enot, plast predstavljenih predmetnosti, plast shematiziranih videzov. Preplet teh plasti v ustrezni receptivni naravnanosti ustvarja po njegovi razlagi polifonijo estetskih vrednostnih kvalitet. Takšna analiza mu je omogočila na eni strani utemeljiti istovetnost literarne umetnine, ${ }^{20}$ na drugi pa razložiti različnost posameznih recepcij in interpretacij, torej različne literarnozgodovinske podobe enega in istega dela. Če zelo poenostavim, sta zlasti prvi dve plasti pomembni za identiteto dela, drugi dve pa omogočata kokreativno vlogo recipienta. Shematizirani videzi in z njimi povezana nedoločena ali prazna mesta so tista strukturna značilnost literarne umetnine, ki tako rekoč kliče recipienta $\mathrm{k}$ dejavni soudeležbi. Ta je tako pomembna, da $\mathrm{v}$ vsakem receptivnem aktu literarno delo zaživi nič manj kot svojo sekundarno eksistenco, v kateri je $\mathrm{v}$ marsikaterem oziru svojsko, drugačno kot $\mathrm{v}$ prvotni in v vseh drugih eksistencah, vendar pa vseskozi ohranja svojo identiteto zaradi zvočno-pomenske fiksiranosti in "shem videzov", ki so fundirani v jezikovnih tvorbah (glej zlasti Ingarden, Literarna 384-409).

${ }^{19}$ Ključno delo je vsekakor Literarna umetnina, ki je prvič izšla 1931, pozneje pa še $\mathrm{v}$ predelanih izdajah 1960 in 1965 . Za razumevanje Ingardnove fenomenološke ontologije literarnega dela pa sta zelo pomembni še dve deli: Vom Erkennen des literarischen Kunstwerks (1968) in Erlebnis, Kunstwerk und Wert (1969).

${ }^{20}$ To je bil v prvi vrsti odgovor sočasnim psihologističnim razlagam (Ingarden, Literarna 42-52), po katerih naj bi literarno delo obstajalo le v psihični dejavnosti bralca. Aktualnost teh izvajanj pa se kaže tudi v kontekstu zagat sodobnega, bolj ali manj "spontanega" historizma, ki zaradi obilice različnih zgodovinskih interpretacij in "podob" kakega besedila razglaša tudi obstoj tega besedila v čisti obliki za fantazijo oziroma fantazmo. Nazoren primer tega so izvajanja Simona Goldhilla in Edith Hall o Sofoklu in tradiciji (Goldhill in Hall 17-18), za kritični komentar prim. Senegačnik, "Hribovškova Antigona» (134-135). 


\section{Antropološko zabrisovanje individualnega}

V zadnjih desetletjih, ko smo priče nekakšnemu socio-historičnemu obratu v akademskem raziskovanju literature, pomen vloge individuuma tako pri nastanku kot $\mathrm{v}$ interpretaciji literarnih del bledi. ${ }^{21}$ To vlogo je vse teže sploh osmisliti v modelih raziskovanja, ki predpostavljajo povsem sistemsko, se pravi brez-osebno proizvajanje pomena $\mathrm{v}$ družbenih diskurzih, med katere sodi literatura. ${ }^{22}$ Teorija recepcije ali recepcijska estetika, ki je sicer $\mathrm{v}$ zasnovi usmerjena $\mathrm{v}$ raziskovanje aktivne vloge bralca pri kreiranju pomena literarnega dela, se je pod vplivom Gadamerjeve hermenevtike razvila predvsem v zgodovinsko preučevanje načinov branja; in prav $\mathrm{v}$ tem pomenu, torej kot oblika sociološkega in historičnega raziskovanja literarne zgodovine, se je uveljavila tudi $\mathrm{v}$ anglosaškem prostoru (the reader response theory). Eden njenih najvidnejših predstavnikov, Wolfgang Iser, je pred desetletji, ko je razvijal teorijo branja na sledi Ingardnove analize literarnega dela (Akt des Lesens, 1976), sicer poudarjal velik pomen individualnega branja, pozneje pa se je usmeril v literarno antropologijo, $v$ raziskovanje splošnih temeljnih značilnosti literature in njihovega pomena za kulturo. V delu The Range of Interpretation (2000) interpretacijo opredeli kot prevajanje in jo opisuje kot kombiniranje treh glavnih metod: poleg Schleiermacherjeve hermenevtike sem šteje še dve ustrezno adaptirani, po izvoru matematični metodi: metodo rekurzivne zanke (the recursive looping) in metodo potujočega diferenciala (the travelling differential). Ali je v razgrinjanju teh metod in njihove kombinatorike prostor za individualni prispevek? Nelahko vprašanje. Zdi se sicer, da bi bile lahko nekatere poteze in kategorije Iserjeve teorije ali, kot sam pravi, konfiguracije interpretacije, povezane $\mathrm{z}$ individualno dejavnostjo interpreta. Tak nastavek se morda skriva $v$ načinu kombiniranja metod, ki je nepredvidljiv in nenadzorljiv, in to v tolikšni meri, da dinamični preplet in igra teh metod dobivata obliko vrtinca (Iser, The Range 148). Morda je povezan s cilji interpretacije; morda $\mathrm{z}$ liminalnim prostorom med znanim in (še) neznanim, v katerem se dogajajo odločitve glede interpretatitvne procedure; morda $\mathrm{z}$ nezavednim, v katerem naj bi se dogajale temeljne odločitve glede te proce-

${ }^{21}$ Seveda to ne pomeni, da sploh ne nastajajo pomembne posamezne študije o individualnih poetikah ali da se individualnost ne osvetljuje $s$ številnih novih, pomembnih perspektiv (prim. Frank in Haverkamp), vendar se zdi vse to izven glavnega toka akademske kulture.

${ }^{22} \mathrm{~V}$ tem oziru seveda ni nič drugače, če je pomen koncipiran kot rezultat sistemsko neukrotljive, nenadzorljive igre, neskončnega gibanja razlike - différance (Derrida 28-29). 
dure (149), a je vse to zelo nejasno. Iser namreč pretežno govori, kakor da te metode delujejo same, da one igrajo svojo igro brez pravil; da se liminalni prostor samoorganizira (149); da na izbor in kombiniranje metod vpliva tema (subject matter) interpretacije, pri čemer pa je ta tema očitno izoblikovana že pred procesom interpretacije - in ni jasno, v kolikšni meri ta izoblikovanost izvira iz splošnih pravil in družbeno vzpostavljenih meril. Podobno tudi ni jasno, ali podzavestno razume kot individualno (»idiosinkratično«) ali pa morda kot oblikovano z vzorci družbenih predstav in vrednot. Po drugi strani pa je res, da v interpretaciji vidi performativno dejavnost (153), proizvodnjo novih fenomenov (151), ki presega področje literature in je neskončen proces, motiviran z nedojemljivostjo človekovega izvora in nezmožnostjo samozapopadenja (155-156). To je zagotovo povezljivo s človekovo individualnostjo, motivacija, ki jo navaja, pa je brez nje celo nesmiselna. Kljub temu pa se Iser o tem ne izrazi eksplicitno: prostor za delovanje individuuma lahko tako bolj naslutimo v nezadostnosti posameznih intepretativnih postopkov, kakor izhajajo iz čisto teoretičnih določil. ${ }^{23}$

Individualni prispevek, sekundarna eksistenca in recepcijski globinski samodoživljaj so težko združljivi s takim čisto negativnim očrtom individuuma. Povezani so z nekoliko drugačnim eksistencialnim odnosom do besedila in izpeljani iz natančneje razdelane zgradbe literarnega dela in bolj kompleksnega opisa recipientove psihološke in ontološke resničnosti. V Ingardnovi in Neumannovi perspektivi recepcija ni izenačena $\mathrm{z}$ interpretacijo kot čisto intelektualno dejavnostjo, zamejeno na področje gole semantike (čeprav so semantične operacije seveda tudi zanju primarne in jedrne). Podobno težko so ti elementi recepcije uskladljivi tudi z idejo interpretacije kot prevajanja nikoli dokončno prevedljivega izvirnika oziroma, kot pravi Iser, prenosa »izvirnika « v neki drug register (Iser, The Range 138, 147, 153). ${ }^{24}$ Ta ideja implicira predstavo dveh ločenih realnosti: »izvirnika« in "prevoda", po kateri je interpretacija (tako kot prevod) reprezentacija ali celo substitucija »izvirnika" v nekem drugem registru. Cilj interpretacije je prav v takšnem "prevodu«; ker pa je prevodnih registrov - in kontekstov, ki jim ti registri pripadajo - več (zanesljivo tudi več, kot jih obravnava Iser),

${ }^{23} \mathrm{Na}$ tak negativni način opredeljuje individualnost že v krajši razpravi »Das Individuum zwischen Evidenzerfahrung und Uneinholbarkeit« iz leta 1987.

${ }^{24}$ Torej ta neprevedljivost ni izvorna »mistična« lastnost besedila, čeprav je gotovo zanimivo, da Iser oblikuje svojo razlago ene od treh metod, potujočega diferenicala, tako, da literarni teoriji prilagodi Rosenzweigovo metodo "prevajanja" neposredne izkušnje Boga v vedenje (Iser, The Range 116). 
je nujno več tudi takšnih "prevodov«, ki pa so vsi nujno nepopolni. Tako razumljena interpretacija se torej začne $\mathrm{z}$ vzpostavitvijo distance do "izvirnika", ki jo Iser imenuje "liminal space«, in je usmerjena od le-tega k "prevodu", kjer je njen cilj (147). V tem smislu lahko najbrž razumemo Iserjeve besede, da interpretacija proizvaja neprevedljivost "izvirnika» (153). A to nikakor ni edina možna "smer« hermenevtike. Interpretacija kot posredništvo med dvema "jezikovnima realnostma" ali med besedilom in bralcem je namreč lahko usmerjena ravno nasprotno, $\mathrm{k}$ »izvirniku" (pri Boeckhu je nedvomno to njena prava smer): ne k "prilastitvi«, "pokritju« le-tega, temveč k njegovi osvetljavi. Ta je vedno segmentalna in perspektivična (v izboru perspektive je interpretov »individualni pristavek", določen tako z njegovim družbenim kontekstom kot z njegovimi "idiosinkratičnimi« potezami in svobodo); vedno je tudi vezana na sekundarno eksistenco literarnega dela in zato (v neki meri) relativna, celo prekarna. Kljub temu pa lahko - kadar je javna - krepi ali celo omogoča umetniški doživljaj tudi v drugih sekundarnih eksistencah (pri branjih, ki niso namenjena oblikovanju nove javne interpretacije, ampak zgolj receptivnemu "užitku«). Njen pomen tudi ni strogo zamejen s sprejemanjem njenih metodoloških predpostavk: odvisno od njene razdelanosti lahko rabi kot izhodišče, dopolnilo ali izziv drugačnim pristopom. ${ }^{25}$ Interpretacijo, ki je razumljena kot (nepopoln) prevod, pa kljub njeni produktivnosti ${ }^{26}$ le težko označimo za kokreativno: njena koncepcija tacite temelji na predstavi o nedosegljivem že izgotovljenem »izvirniku" (ta ni le, ingardnovsko rečeno, fundament, na katerem se v kokreativnih interpretativno-recepcijskih dejih oblikujejo sekundarne različice modificirane celote), ki ga "prevodi« v druge registre neuspešno nadomeščajo.

${ }^{25}$ Vse to je močno odvisno od hermenevtične etike posameznega interpreta, pa tudi od raziskovalne oziroma kulturne politike, ki pomembno vpliva na družbeno "vidnost" posameznih interpretativnih pristopov in lahko pomembno podpira ali pa zatira hermenevtično etiko odprtosti, komunikativnosti in zlasti občutljivosti.

${ }^{26}$ Interpretacija, katere cilj je omogočiti delovanje stvari, vedno povzroča, da se nekaj pojavlja: "Whenever interpretation occurs, something emerges." (Iser, The Range 151) Vse pa, kar se na ta način pojavlja, „the emergent phenomena» (152), je zarisovanje resničnosti, v kateri živimo, oziroma orisovanje le-te z množico svetov (154). Zdi se mi, da bi to "povzročanje pojavljanja« natančneje opisal izraz odkrivanje kot pa proizvajanje. 


\section{Razkroj individualnega: znanost o literaturi ali iluzija?}

Na splošno pa je zlasti v akademskem raziskovanju literature najti manj zanimanja za vlogo individuuma $v$ interpretaciji (in pri nastajanju) literarnih del. Načelna težnja znanosti je seveda objektivno vedenje, ki ni kompatibilno $\mathrm{z}$ neujemljivim "subjektivnim" nihanjem individualnih izkušenj z besedili. Želja dati temu individualnemu objektivno obliko, stabilizirati jo $\mathrm{v}$ okviru teoretičnih pojmov se značilno kaže $\mathrm{v}$ potrpežljivih Ricoeurjevih poskusih shematizacije in depersonalizacije delovanja metafore: Ricoeur sicer nikakor ne želi izpustiti iz svoje pedantne analize psiholoških (neverbalnih, čutnih) elementov, ki so za to delovanje očitno vitalnega pomena, obenem pa želi psihologijo vendarle povezati s semantiko na shematičen, znanstven način (glej Ricoeur 316; pa tudi celo poglavje o psiho-lingvistiki metafore, 305-326), ki bi nevtraliziral delovanje »duše«, torej neshematizabilni individualni moment (Ricoeur 333).

$\mathrm{V}$ Bourdieujevi poststrukturalistični kritični interpretaciji individualnega sloga pa je razvidna tudi želja po tem, da bi individuum oziroma njegovo jezikovno pojavno obliko, slog, odpravil kot iluzijo ali epifenomen: individualni slog je zanj samo različica, absorbirana $\mathrm{v}$ strukturi (Bourdieu 90) oziroma »odklon, značilen le za neko obdobje ali družbene razrede« (103). Tu Bourdieu govori o "osebnem« slogu: narekovaji okrog izraza "osebni« imajo seveda ontološki pomen, ker zanikajo dejanski obstoj individualne osebnosti v smislu relevantne instance v jeziku. »To je sicer mogoče, a popolnoma arbitrarno stališče; tak pojem strukture je tako zelo raztegljiv in interpretativno uporaben, da je navsezadnje neuporaben; mistificirana ( $v$ bistvu metafizična $v$ najslabšem pomenu besede) domneva o njeni apriornosti in vsezaobsegajočnosti predvsem usmerja interpretovo pozornost proč od vsega individualnega in sugerira obvladljivost (jezikovne, družbene, kulturne) resničnosti z modelom." (Senegačnik, "Štirje« 170) Brez "mistificiranega" pojma strukture lahko utemeljimo takšno stališče samo tako, da že vnaprej razglasimo vse dejanske posebnosti individualnih slogov za odklone ali variante splošnega sloga in potem "ugotavljamo" splošne poteze $\mathrm{v}$ individualnih izrazih - a to je petitio principi.

Poleg teh zagat in nepraktičnosti za raziskovanje literarnih del kaže Bourdieujeva teorija praktičnega čuta v zvezi s problemom individualnosti in subjekta še eno zanimivo potezo: prenos klasičnih lastnosti človeškega subjekta (spontanosti, refleksivnosti, kavzalnega delovanja) na neko brezosebno abstrakcijo, ki postane s tem edina prava instanca $\mathrm{v}$ delovanju jezika. Ta entiteta je pri Bourdieuju habitus, ki občasno deluje 
tudi povsem človeško: "poskuša» (Bourdieu 95), "snuje (96), »izkorišča», »resno jemlje« (98), itd. Vendar takšen prenos ni posebnost teorije praktičnega čuta; podoben postopek je opazen še pri nekaterih vplivnih (post) strukturalističnih piscih: npr. pri Althusserju, Lacanu, Derridaju (prim. Frank, Das Sagbare 270). ${ }^{27} \mathrm{Zdi}$ se, da lahko tu upravičeno govorimo o personifikaciji (četudi nepriznani) brezosebnega in da je ta personifikacija teoretično bolj vprašljiva od "romantične« personifikacije antičnih besedil; pri poststrukturalistih gre namreč za radikalen, absoluten prenos osebnega na brezosebno, medtem ko romantično poosebljenje vendarle temelji na premisi o besedilu kot rezultatu individualne uporabe splošnih pravil. Strukturalistične subjektivizacije abstrakcij pa imajo bržčas tudi daljnosežnejše posledice. Ključnega pomena je namreč, da takšna naravnanost oz. neobčutljivost za individualno končno vpliva tudi na nastajanje literature: $\mathrm{z}$ nevero $\mathrm{v}$ individualnost, $\mathrm{z}$ njenim raztapljanjem $\mathrm{v}$ splošnem se izgublja tudi motivacija za njeno izražanje v literarnem slogu. »Individualni pristavek" postane tako odveč.

\section{LITERATURA}

Betti, Emilio. Teoria generale della interpretazione. Milano: Giuffrè, 1955.

Boeckh, August. Encyklopädie und Methodologie der philologischen Wissenschaften. Ur. Ernst Bratuschek. Leipzig: Teubner, 1877 (nespremenjen ponatis: Darmstadt: Wissensschaftiche Buchgesellschaft 1966).

Boeckh, August. "Über die Antigone des Sophokles«. Abhandlungen der historischphilologischen Klasse der königlichen Akademie der Wissenschaften zu Berlin aus dem Jahre 1828. Berlin: Akademie der Wissenschaften, 1831. 49-112.

Bourdieu, Pierre. Praktični čut I. Ljubljana: Studia humanitatis, 2002.

Danneberg, Lutz. "Ganzheitsvorstellungen und Zerstückelungsphantasien. Zum Hintergrund und zur Entwicklung der Wahrnehmungen ästhetischer Eigenschaften in der zweiten Hälfte des 18. und zu Beginn des 19. Jahrhunderts«. Mimesis Repräsentation - Imagination: Literaturtheoretische Positionen von Aristoteles bis zum Ende des 18. Jahrhunderts Ur. Jörg Schönert in Ulrike Zeuch. Berlin: de Gruyter, 2004. 241-282.

Danneberg, Lutz. "Kunst, Methode und Methodologie bei Boeckh». Ur. Christiane Hackel in Sabine Seifert. Berlin: Berliner Wissenschafts-Verlag, 2013. 211-242.

Derrida, Jacques. Positions. Chicago, IL: The University of Chicago Press, 1981.

Doborosky, Julia. Der Philologiebegriff August Boeckhs im Spiegel seiner privaten Büchersammlung (Berliner Intellektuelle um 1800). Berlin: Berliner WissenschaftsVerlag, 2020.

Forster, Michael N. „Schleiermacher's Hermeneutics: Some Problems and Solutions». The Harvard Review of Philosophy 13.1 (2005): 100-122

${ }^{27}$ Zanimivo je, da lahko paralele takšne personifikacije brezosebnih, abstraktnih teoretičnih bitnosti najdemo že pri poznostoiškemu filozofu Epiktetu, čeprav gre morda pri njem za metonimijo (Senegačnik, »Štirje« 169). 
Frank, Manfred, in Anselm Haverkamp, ur. Individualität. München: Wilhelm Fink Verlag, 1988.

Frank, Manfred. „Besedilo in njegov slog: Schleiermacherjeva teorija jezika". Nova revija 304/306 (2007): 208-224.

Frank, Manfred. Das Sagbare und das Unsagbare. Studien zur französischcen Hermeneutik und Texttheorie. Frankfurt am Main: Suhrkamp, 1989.

Frank, Manfred. Selbstbewußtsein und Selbsterkenntnis. Stuttgart: Reclam, 1991.

Goldhill, Simon, in Edith Hall, ur. Sophocles and the Greek Tragic Tradition. Cambridge: Cambridge University Press, 2009.

Güthenke, Constanze. Feeling and Classical Philology. Knowing Antiquity in German Scholarship, 1770-1920. Cambridge; New York, NY: Cambridge University Press, 2020.

Hackel, Christiane, in Sabine Seifert, ur. August Boeckh. Philologie, Hermeneutik und Wissenschaftspolitik. Berlin: Berliner Wissenschafts-Verlag, 2013.

Hirsch, Eric D. Jr. Validity in Interpretation. New Haven, CT: Yale University Press, 1967.

Hirsch, Eric D. Jr. The Aims of Interpretation. Chicago, IL: University of Chicago Press, 1976.

Humboldt, Wilhelm von. Gesammelte Schriften. Bd. 5. Berlin: Walter de Gruyter, 1968.

Ingarden, Roman. Vom Erkennen des literarischen Kunstwerks. Tübingen: Max Niemeyer, 1968.

Horstmann, Axel. Antike Theoria und moderne Wissenschaft. August Boeckhs Konzeption der Philologie. Frankfurt am Main: Peter Lang, 1992.

Ingarden, Roman. Erlebnis, Kunstwerk und Wert. Vorträge zur Ästhetik 1937-1967. Tübingen: Max Niemeyer, 1969.

Ingarden, Roman. Literarna umetnina. Ljubljana: Studia humanitatis, 1990.

Iser, Wolfgang. "Das Individuum zwischen Evidenzerfahrung und Uneinholbarkeit«. Individualität. Ur. Manfred Frank in Anselm Haverkamp. München: Wilhelm Fink Verlag, 1988. 95-98.

Iser, Wolfgang. The Range of Interpretation. New York, NY: Columbia University Press, 2000.

King, Colin G. "August Boeckh in the 21st Century: Methodological Questions for Globalized Classics«. Journal of the History of Ideas Blog. Splet. 18.3.2021. <https://jhiblog.org/2015/08/24/august-boeckh-in-the-21st-century-methodological-questions-for-globalized-classics/>.

Lane, Melissa. S. Plato's Progeny. How Plato and Socrates still Captivate the Modern Mind. London: Duckworth, 2001.

Neumann, Erich. Der schöpferische Mensch. Zürich: Rhein, 1959.

Pfeiffer, Rudolf. Geschichte der klaissischen Philologie. Reinbek bei Hamburg: Rowohlt, 1970.

Poiss, Thomas. "August Boeckhs Pindar-Studien«. August Boeckh. Philologie, Hermeneutik und Wissenschaftspolitik. Ur. Christiane Hackel in Sabine Seifert. Berlin: Berliner Wissenschafts-Verlag, 2013. 27-44.

Poiss, Thomas. "Die unendliche Aufgabe. August Boeckh als Begründer des Philologischen Seminars". Die modernen Väter der Antike: die Entwicklung der Altertumswissenschaften an Akademie und Universität im Berlin des 19. Jahrhunderts. Ur. Annette M. Baertschi in Colin G. King. Berlin: de Gruyter, 2009. 45-72.

Ricoeur, Paul. 1975. Živa metafora. Ljubljana: KUD Apokalipsa, 2009.

Ringler, Wiliam. "Poeta Nascitur Non Fit: Some Notes on the History of an Aphorism«. Journal of the History of Ideas 2.4 (1941): 497-504. 
Schleiermacher, Friedrich. Hermeneutik und Kritik. Mit einem Anhang sprachphilosophischer Texte Schleiermachers. Ur. Manfred Frank. Frankfurt: Suhrkamp, 1977.

Seebohm, Thomas M. "The Problem of Hermeneutics in Recent Anglo-American Literature: Part I«. Philosophy \& Rhetoric 10.3 (1977): 180-198.

Segal, Charles. "Introduction: Retrospection on Classical Literary Criticism". Contextualizing Classics. Ideology, Performance, Dialogue. Essays in honor of John J. Peradotto. Ur. Thomas M. Falkner, Nancy Felson in David Konstan. Lanham, Md.: Rowman \& Littlefield, 1999. 1-15.

Senegačnik, Brane. »Hribovškova Antigona in njen kontekst."Sofoklova Antigona $v$ prevodu Ivana Hribovška. Ur. David Movrin. Ljubljana: Družina, 2014. 109-151.

Senegačnik, Brane. "Štirje dolgi pripisi h kratki zgodbi o ljudeh brez zgodbe«. Nova revija 336-338 (2010): 167-184.

Senegačnik, Brane. "Individualnost in problem interpretativnega obzorja." Annales, Series Historia et Sociologia 29.4 (2019): 589-602.

Staiger, Emil. Die Kunst der Interpretation. Studien zur deutschen Literaturgeschichte. Zürich: Atlantis Verlag, 1955.

Steinberg, Michael P. Listening to Reason. Culture, Subjectivity, and Nineteenth-Century Music. Princeton, NJ; Oxford: Princeton University Press, 2004.

Tessier, Andrea. „De pauore uersus seiungendi. 'Riscoperta' del verso melico greco (Böckh 1811) e sua ricezione novecentesca."Incontri triestini di flologia classica 7 (2007-2008): 1-16

Tessier, Andrea. »'Sticometria' e misura del verso melico greco: Böckh«. Quaderni Urbinati di Cultura Classica 88.1 (2008): 121-124.

Vernant, Jean-Pierre, in Pierre Vidal-Naquet. Tragedy and Myth in Ancient Greece. Prev. Janet Lloyd. New York, NY: Zone Books, 1988.

Willett, Steve J. „Working Memory and its Constraints on Colometry«. Quaderni Urbinati di cultura classica 71 (2002): 7-19.

\section{August Boeckh, Classical Philologist and Hermeneut}

Keywords: Boeckh, August / classical philology / hermeneutics / interpretation / reception theory / Schleiermacher, Friedrich / Ingarden, Roman / Iser, Wolfgang / Bourdieu, Pierre / Ricoeur, Paul

August Boeckh is one of the most important classical scholars of the nineteenth century. His vast and varied oeuvre forms an excellent starting-point for reflecting concepts, fields, methods, and epistemological limitations (and nowadays the intercultural dialogue) of Classical Philology or Classical Studies. In addition, Boeckh was an influential methodologist and an early theorist of hermeneutics. On the grounds of Friedrich Schleiermacher's work, he built a branching system of philological methodology, defining the aim of philol- 
ogy as "the recognition of something already recognised before." Particularly typical of his theory is the emphasis on the role played by human individuality both in the creation and explication of texts. Rather than conceptually, individuality can be known and defined only through intuition (durch lebendige Anschauung). This idea is of historical importance, for individuality had a major role in the phenomenological and psychological interpretations of literary works in the twentieth century, including in reception theory. In contemporary anthropological, cognitive, and social-science models of literature research, however, it is losing its purpose and meaning, which necessarily affects the prevailing apprehension of literature.

1.01 Izvirni znanstveni članek / Original scientific article

UDK 801.73: [821.124+821.14].09

DOI: https://doi.org/10.3986/pkn.v44.i2.07 